\title{
Selective Staining of Large Projection Neurons by Monoclonal Antibody to a Glycoprotein of PC12 Cells
}

\author{
P. Sajovic, E. Moraru, L. A. Greene, and M. L. Shelanski \\ Department of Pharmacology, New York University Medical Center, New York, New York 10016
}

\begin{abstract}
A monoclonal antibody has been produced against glycoproteins prepared from PC12 cells. This antibody stains PC12 cells in a rimlike fashion, whether they are fixed or living. When neuronally differentiated PC12 cells are used, neurites as well as somata stain. In the presence of complement, the antibody is cytotoxic to PC12 cells. These lines of evidence suggest that at least some of the binding is to an exposed component of the plasma membrane in these cells. Biochemical experiments directed at identifying the antigen(s) indicate specific recognition of glycoproteins of apparent molecular weights of $\sim 160$ and 95 kDa by SDS-PAGE. The antibody appears to be directed against a determinant on the protein moiety. The larger species is likely to be the same as a glycoprotein previously described (Lee et al., 1981), which has been found in PC12 cells, but not in brain. The monoclonal antibody we have produced, however, selectively stains a subset of neurons in brain. Specifically, it binds to Purkinje cells in cerebellar cortex, pyramidal cells in cerebral cortex and hippocampus, ganglion cells in retina, and some neurons, generally large, in most brain structures examined. No glia or nonneural tissues stain. We suggest that the neurons recognized by this antibody may be the projection cells of each structure. However, in contrast to PC12 cells, the antigen(s) bound in this case appears to be predominantly internal. This interpretation is supported by the appearance of stained cells in tissue; by the failure of the antibody to stain live dissociated neurons from brain; and by its failure to lyse sympathetic neurons in the presence of complement. Western immunoblots show that there is glycoprotein present in brain that is recognized by the antibody, and that it is enriched in a crude microsomal fraction prepared from that tissue. This material migrates on SDS gels as two bands of 130 and $95 \mathrm{kDa}$.
\end{abstract}

Several lines of evidence suggest that the development and functioning of the mature vertebrate nervous system require the expression of many genes specific to it. Immunological techniques have identified several molecules characteristic of neurons and glia, of known or unknown function (Celio and Heizmann, 1981; Edelman, 1984; Faissner et al., 1984; Hawkes et al., 1982b; Jorgenson, 1981; Lohmann et al., 1981, Rougon et al., 1982; Schnitzler et al., 1984a, b; Webb and Barclay, 1984; Zomzely-Neurath and Walker, 1980). Many of these are cellsurface membrane glycoproteins (Braun et al., 1981; Cohen and Selvendran, 1981; Edelman, 1984; Faissner et al., 1984; Reeber et al., 1981; Rougon et al., 1982; Salton et al., 1983a, b; Schnitzler et al., 1984a, b; Vulliamy et al., 1981; Webb and Barclay,

Received Feb. 7, 1985; revised June 3, 1985; accepted July 16, 1985.

We thank Kristy Brown and Humberto Diaz for technical assistance; Dr. M. E. Hatten for suggesting the low-pH and hyaluronidase pretreatments as a way of improving tissue staining; and Drs. R. K. H. Liem, M. Butler, C. Mason, and E Trenkner, as well as members of the Pharmacology Department, for helpful advice and discussions. This work was supportcd by Grant NS16839 to M.L.S. and L.A.G. and NIH Postdoctoral Training Grant NS07178 to P.S.

Correspondence should be addressed to Dr. Peter Sajovic, Department of Pharmacology, NYU Medical Center, 550 First Avenue, New York, NY 10016.

Copyright (C) 1986 Society for Neuroscience $0270-6474 / 86 / 010082-12 \$ 02.00 / 0$
1984). Several immunohistochemical studies have appeared that indicate the existence of antigenic molecules that are restricted to particular regions or structures of the brain, or to particular types of neurons (Akeson and Warren, 1984; Buckley et al., 1983; Cohen and Selvendran, 1981; Garson et al., 1982; Hawkes et al., 1982a; Levitt, 1984; McKay and Hockfield, 1982; Reeber et al., 1981; Vulliamy et al., 1981; Weber and Schachner, 1982; Woud et al., 1982). Such molecules are likely to be of interest from the point of view of understanding the organization and functioning of the brain.

The PC12 clonal line of rat pheochromocytoma cells has become established as a useful model system for the study of many aspects of neuronal cell biology (Greenc and Tischler, 1982). These cells resemble adrenal chromaffin cells; however, when treated with nerve growth factor (NGF), they acquire many phenotypic properties of sympathetic neurons. Because they are a uniform and convenient model system, several immunochemical and biochemical investigations have been directed towards using them to study neuronal glycoproteins (Lee et al., 1980a, 1981; Margolis et al., 1983; McGuire et al., 1978; RichterLandsberg et al., 1984; Salton et al., 1983a, b). A number of large antigenic surface glycoproteins have been found in $\mathrm{PC} 12$ cells (apparent $M_{r}$ s of $230,180,160,140$, and $116 \mathrm{kDa}$ by SDSPAGE), and some of them (the 230, 180, and $140 \mathrm{kDa}$ species) were shown by immunoabsorption studies to be present in brain, but not many other tissues (Lee et al., 1981). The $140 \mathrm{kDa}$ species appears to be equivalent to the D2 or neuronal cell adhesion molecule (N-CAM) (Edelman, 1984; Jorgenson, 1981; Rougon et al., 1982), while the $230 \mathrm{kDa}$ component, which is induced in PC12 cells by treatment with NGF (and therefore was called the NGF-Inducible Large External, or NILE, glycoprotein), appears to be a general marker of neurons.

To extend our knowledge of the high-molecular-weight glycoproteins of $\mathrm{PC} 12$ cells with respect to their functions and localization in normal tissue, we have made a non-SDS-denatured preparation that is highly enriched in these components and have used it to generate monoclonal antibodies (mAb). In this paper, we report that one of these antibodies, which recognizes the $160 \mathrm{kDa}$ glycoprotein of PC12 cells as well as a second component at $95 \mathrm{kDa}$, selectively stains a subset of CNS neurons that seems to include the large projection cells of many brain structures, such as cerebellar Purkinje cells and the pyramidal cells of the cerebral cortex. Evidence is presented that indicates that the component of normal neurons recognized by the antibody is internal, and that it consists of two electrophoretic bands in SDS gels (130 and $95 \mathrm{kDa}$ ), one of which has a mobility indistinguishable from the lower of the PC12 cell proteins.

\section{Materials and Methods}

\section{Preparation of antigen}

PC12 cells were grown as previously described (Greene and Tischler, 1976). For the preparation of antigen, cells not exposed to NGF were 
solubilized in $1 \%$ sodium deoxycholate and $20 \mathrm{~mm}$ Tris- $\mathrm{HCl}$, pH 7.8, with $5 \mathrm{~mm}$ phenylmethylsulfonyl fluoride (PMSF) and $0.01 \%$ aprotinin, and the extract was centrifuged $\left(100,000 \mathrm{~g}\right.$ for $60 \mathrm{~min}$ at $\left.20^{\circ} \mathrm{C}\right)$ to pellet DNA and particulates. The supernatant was diluted with $20 \mathrm{~mm}$ Tris$\mathrm{HCl}$ to $0.2 \%$ deoxycholate and passed over a column of wheat germ agglutinin (WGA)-Sepharose which, after washing, was eluted with 0.2 $\mathrm{M} \mathrm{N}$-acetylglucosamine in $20 \mathrm{~mm}$ Tris- $\mathrm{HCl}$ (same $\mathrm{pH}$ ) and $0.2 \%$ deoxycholate. The eluate was reconcentrated to small volume $(0.5 \mathrm{ml}$ or less) by vacuum dialysis and injected into a Beckman high-pressure liquid chromatography (HPLC) sizing column (TSK 3000) previously equilibrated with the same buffer. The HPLC column was run at a low flow rate $(0.1-0.2 \mathrm{ml} / \mathrm{min})$ and five size fractions were routinely recovered. The first of these contained most of the high-molecular-weight glycoproteins (see Results), and was reconcentrated by vacuum dialysis for use as the antigen.

\section{Preparation, screening, and cloning of hybridomas}

The procedures used generally followed published protocols (Galfre and Milstein, 1981; Kennet et al., 1980; Kohler and Milstein, 1975). BALB/C mice were injected subcutaneously four times with antigen emulsified in Freund's adjuvant; the original injection contained about $50 \mu \mathrm{g}$ total protein, and each booster about one-quarter as much. All injections were delivered under each hindleg and in both footpads, at 1-week intervals. Immunized mice were killed by cervical dislocation and spleens dissected out sterilely. Spleen cells were dissociated by trituration, fused to NS-1 myeloma cells with polyethylene glycol 4000 , spun down, and plated in hypoxanthine-aminopterin-thymidine (HAT) medium. This regime was maintained for 2 weeks to kill unfused cells, at which time the cells were transferred to medium without aminopterin [hypoxanthine-thymidine (HT) medium]. A week later, survivors were screened and positives taken up, counted, and subcultured in Falcon 96-well culture dishes at 1000 cells/well. After these wells had grown to high density, supernates were screened (see below) and positive cultures replated at 10 cells/well. Screening was repeated and positives replated at an average of $1 \mathrm{cell} / \mathrm{well}$; at this point the hybridomas were placed in wells previously seeded with macrophage feeder layers prepared as described (Michl et al., 1979). Positive cultures were recloned once more by limiting dilution before being expanded for the production of antibody.

Two types of screening procedure were employed. In the first, a complete deoxycholate extract of PC1 2 cells (with DNA removed by centrifugation) was applied to small circles of nitrocellulose paper (Biorad) in wells. These were treated with 5\% BSA and then incubated overnight with hybridoma supernatants. After washing with PBS $(3 \times 5 \mathrm{~min})$, the paper was exposed for $1 \mathrm{hr}$ to rabbit anti-mouse antiserum (1:20), washed $3 \times 5$ min again, and incubated with $I^{125}$ protein $A$ for $1 \mathrm{hr}$. After final washes, the paper circles were counted and background counts (from paper exposed to culture medium without cells) subtracted. The second screening method used was fluorescent staining of PC12 cells; this protocol is described below, with hybridoma supernatant serving as the first antibody. Staining potency was measured by a subjective 5-point scale, and those cultures were selected at each stage that scored best on both the radioactive-binding and cell-staining assays.

\section{Production of monoclonal antibodies}

Culture supernatants were collected and concentrated by ammonium sulfate precipitation, as described (Heide and Schwics, 1973). Ascites fluids were produced by injecting pristane-primed $B A L B / C$ mice with about $10^{7}$ hybridoma cells and draining the peritoneal cavity repeatedly after tumors became grossly apparent. IgM fractions were oblained in two ways. Culture supernatants were concentrated by ammonium sulfate precipitation and chromatographed on a column of LKB Ultrogel 350 (length $40 \mathrm{~cm}$, bed vol $190 \mathrm{ml}$ ) overnight at $8 \mathrm{ml} / \mathrm{hr}$. The void volume contained the staining activity and polypeptides of SDS-PAGE molecular weights corresponding to IgM heavy and light chains. Other IgM preparations were obtained by passing ascites fluids over a column of protein A-Sepharose, which was then washed with $\mathrm{pH} 8.0$ phosphate buffer and eluted with $100 \mathrm{ml} \mathrm{pH}$ gradient (6.0-3.0) of citrate-phosphate buffer. Twenty-five $4 \mathrm{ml}$ fractions were collected and assayed both by SDS-PAGE and by the ability to stain PC12 cells (see below). Again, staining activity and IgM-sized polypeptides were found in the same fractions. The relevant fractions, however, were eluted at the low $\mathrm{pH}$ end of the gradient (pH 3.5-4.5), indicating a high affinity of the IgM for protein A-Sepharose. The class of the active component was confirmed by Ouchterlony immunodiffusion assay, performed according to published methods (Ouchterlony, 1968), using commercial anti-mouse antisera (Cappel).

Preabsorbed antibody for use as a control was prepared by incubating ascites or IgM preparations twice with an equal packed volume of live $\mathrm{PCl} 2$ cells for $1 \mathrm{hr}$ while rotating at room temperature; cells were spun out and the absorbed preparation used at the same dilution as the relevant $\mathrm{mAB}$.

\section{Immunofluorescence staining of cultured cells}

Cultured cells were grown on glass slides or coverslips utilizing appropriate substrata (collagen for PC12 cells and sympathetic neurons, polylysine for cerebral cortex neuronal dissociate cultures; see below). Cells (of passage numbers 28-39) were fixed by immersion in 4\% paraformaldehyde in PBS for 5-15 min, washed in PBS, and incubated in blocking solution (either $10 \%$ normal goat serum or $1 \%$ BSA in PBS) for $30 \mathrm{~min}$. After washing, coverslips were incubated in first antibody (usually ascites fluid at 1:100 dilution or IgM fraction at $0.01 \mathrm{mg} / \mathrm{ml}$ final concentration) for $1 \mathrm{hr}$ at room temperature. They were then washed $3 \times$ $10 \mathrm{~min}$ with PBS and incubated with fluorescein-conjugated goat antimouse antiserum (Cappel) at 1:100 dilution for $1 \mathrm{hr}$, washed again $3 \times$ $10 \mathrm{~min}$ in PBS, and mounted in polyvinyl alcohol-glycerol.

\section{Immunofluorescent staining of tissue}

Mouse and rat tissues were dissected out after fixation by ventricular perfusion with $4 \%$ paraformaldehyde in PBS. They were then immersed in 1:1 fixative : $20 \%$ sucrose in PBS: until the tissue sank, then transferred to $20 \%$ sucrose in PBS and kept in the refrigerator overnight. Frozen sections were cut at $10-20 \mu \mathrm{m}$ on an AO Histostat cryostat and picked up on glass slides. The slides were washed by immersion in PBS

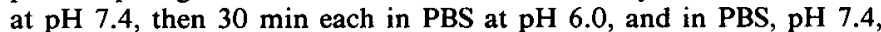
containing $10 \mu \mathrm{g} / \mathrm{ml}$ hyaluronidase (Boehringer Mannheim). Following incubation with hyaluronidase, the sections were washed briefly with PBS and incubated overnight with primary antibody (dilutions between $1: 100$ and $1: 500)$ at $4^{\circ} \mathrm{C}$. The next day, slides were washed $3 \times 30 \mathrm{~min}$ with PBS and transferred to fluorescent second antibody at $1: 100(4 \mathrm{hr}$ or overnight). After final washes $(3 \times 30 \mathrm{~min}$ with PBS), the slides were mounted with polyvinyl alochol-glycerol and examined.

\section{Immunoperoxidase staining of cultured cells and tissue}

Immunoperoxidase staining was done with Vectastain biotin-avidinperoxidase kits (Vector Labs), following recommended procedures. Tissue culture cells were processed as for fluorescence, except that after primary antibody the Vectastain procedure was followed. Color development was with $0.3 \mathrm{mg} / \mathrm{ml}$ diaminobenzidine in $50 \mathrm{~mm}$ Tris, pH 7.6 , plus $0.006 \% \mathrm{H}_{2} \mathrm{O}_{2}$

Brain tissue to be stained with immunoperoxidase was embedded in albumin-gelatin directly after perfusion and $50 \mu \mathrm{m}$ sections were cut on a Vibratome. The sections, floating in individual wells, were processed as above through PBS wash, low-pH PBS wash, hyaluronidase, and first antibody. Subsequent processing was according to the Vectastain protocol. Sections were dehydrated in ethanol series, cleared in xylene, and mounted in Permount. In some experiments, alternate sections were counterstained with cresyl violet.

\section{Processing of immunoperoxidase stained tissue for EM}

Sections from one brain successfully stained with immunoperoxidase were further processed for electron microscopy. Segments of cerebral cortex were cut by razor blade out of stained sections and embedded in Epon according to standard techniques. These blocks were sectioned at $1 \mu \mathrm{m}$ and examined in the light microscope to locate small areas containing well-stained cells. Several such $1 \mu \mathrm{m}$ sections were then exposed to $1 \%$ osmium tetroxide, remounted on blank Epon blocks, trimmed, and thin-sectioned on a Sorvall MT 5000 ultramicrotome. Silver gray sections were picked up on mesh grids and examined in a JEOL 100C microscope.

\section{Dissociated cell culture of cerebral cortex and superior cervical ganglia (SCG)}

Rat embryos of 15 to 16 days' gestational age (E15-E16) were used to prepare dissociated cell cultures of cerebral cortex, according to methods modified from Dichter (1978) and Hatten and Francois (1981). Pregnant mothers were killed by cervical dislocation and uterine segments dissected out on a benchtop; subsequent procedures were carried out in a sterile hood. Cerebral cortices were dissected from the embryos, placed in a drop of sterile PBS, and the meninges were carefully stripped away. 
The tissue was then minced and incubated in $0.0125 \%$ trypsin for 2 min, washed with culture medium (see below), and disrupted by triturating through Pasteur pipets of increasingly narrow apertures. Undissociated tissue was exposed to DNAase $I\left(100\right.$ units $/ \mathrm{ml}$ in PBS with $\mathrm{Ca}^{2+}$ and $\mathrm{Mg}^{2+}$ ) for 3-5 min, then returned to culture medium and triturated. Clumps were allowed to settle for $5 \mathrm{~min}$, at which time the cell suspension was placed in a fresh tube and centrifuged at $1000 \mathrm{~g}$ for $5 \mathrm{~min}$. The pellet was resuspended in fresh medium, the cells were counted and plated on polylysine-coated culture dishes or coverslips at $10^{5}-10^{6}$ cells $/ \mathrm{ml}$. These cultures were maintained in beta-mercaptoethanol (BME) with $10 \%$ fetal calf serum and $0.2 \%$ glucose. Cultures were short-term (4-8 d), and feeder layers of nonneuronal cells were not used.

Dissociated cell cultures of superior cervical ganglion (SCG) from newborn rats were prepared as previously described (Lee et al., 1980b), and maintained 2-4 $\mathrm{d}$ before staining.

\section{Cytotoxicity assays}

To measure complement-mediated cytotoxicity, cells plated at low density were exposed to medium (RPMI 1640) with $10 \%$ sterile filtered ascites fluid and 10\% sterile filtered fresh-thawed guinea pig complement (Pocono Hills Rabbit Farms). Control dishes were incubated with 20\% ascites, $20 \%$ complement, or RPMI with $10 \%$ horse serum and $5 \%$ fetal calf serum. Cell death was estimated visually or by trypan blue exclusion at $10 \mathrm{~min}$ intervals.

\section{Western immunoblots}

Whole cell or tissue SDS extracts, or glycoprotein fractions prepared as described from PC12 cells or brain, were analyzed in immunoblot experiments. For experiments on inhibition of glycosylation, cells were incubated for $72 \mathrm{hr}$ with or without tunicamycin (Calbiochem) at $5 \mu \mathrm{g} /$ $\mathrm{ml}$, plus tritiated fucose at $10 \mu \mathrm{Ci} / \mathrm{ml}$. Cells were washed three times, solubilized in sample buffer, and boiled. Aliquots were trichloroacetic acid (TCA)-precipitated and counted to determine the extent of inhibition ( $90-95 \%$ in the experiments reported here). To compensate for effects on protein synthesis, gel-loading was determined according to a Lowry protein assay. Samples were resolved by SDS-PAGE and transferred electrophoretically to nitrocellulose sheets for $12 \mathrm{hr}$ in a blotting buffer consisting of $96 \mathrm{~mm}$ glycine, $12.5 \mathrm{~mm}$ Tris, $10 \%$ methanol, and $10 \mathrm{~mm}$ beta-mercaptoethanol. Following transfer, strips of paper were incubated in a blocking solution of 5\% BSA in PBS; other strips were stained with amido black or Fast green to reveal molecular weight markers and total transferred protein. The blocked strips were sequentially incubated with primary antibody (usual dilutions: ascites fluid, 1:100; IgM fraction, $0.01 \mathrm{mg} / \mathrm{ml}$ ) and Vectastain reagents (biotinylated anti-mouse antibody and avidin-peroxidase complex) at recommended dilutions. Between incubations, strips were washed $5 \times 5 \mathrm{~min}$ in PBS. Color development was with diaminobenzidine, as specified above for tissue staining.

\section{Prolein A-Sepharose immunoprecipitation}

$\mathrm{PC} 12$ cells were labeled with ${ }^{3} \mathrm{H}$-fucose (NEN) at $10 \mu \mathrm{Ci} / \mathrm{ml}$ for $72 \mathrm{hr}$, then extracted in an immunoprecipitation buffer: $190 \mathrm{~mm} \mathrm{NaCl}, 50 \mathrm{~mm}$ Tris, $2.5 \%$ Triton X-100, 0.1\% SDS, 6 mM EDTA, and 2 mM PMSF. Nonspecific binding to protein A-Sepharose was eliminated by preincubation. The cleaned extract was incubated 1:10 with preimmune serum, and then overnight with antibody (IgM $0.1 \mathrm{mg} / \mathrm{ml}$ combined with an equal volume of extract), rotating at $4^{\circ} \mathrm{C}$. Swollen protein A-Sepharose was added (50-100 mg/tube in different experiments) and incubation continued ( $4 \mathrm{hr}$ to overnight). Beads were spun down, washed $3 \times$ in immunoprecipitation buffer without detergent, and boiled in sample buffer. Samples were resolved by SDS-PAGE and the labeled proteins visualized by fluorography (Bonner and Laskey, 1974; Laskey and Mills, 1975).

\section{Fractionation of brain tissue}

Adult rat brains were dissected out of animals killed by $\mathrm{CO}_{2}$ asphyxiation and immersed in $0.32 \mathrm{M}$ sucrose, $20 \mathrm{~mm}$ Tris, $\mathrm{pH} \mathrm{7.6}$, with $5 \mathrm{~mm}$ PMSF and $0.01 \%$ aprotinin. They were homogenized with 10 strokes of a Teflon homogenizer at $750 \mathrm{rpm}$. Nuclei were pelleted by centrifugation at $1000 \mathrm{~g}$ for $5 \mathrm{~min}$. The supernatant was spun at $12,000 \mathrm{~g}$ for $20 \mathrm{~min}$ to obtain a crude synaptosomal pellet. The corresponding supernatant was further centrifuged at $100,000 \mathrm{~g}$ for $1 \mathrm{hr}$ to obtain a crude microsomal pellet and a soluble fraction. All these steps were done on ice or at $4^{\circ} \mathrm{C}$. Synaptosomal, microsomal, and soluble fractions were taken up separately in deoxycholate buffer, and glycoproteins prepared from each by use of a WGA column, as described above; these eluates wcrc dialyzed against an SDS running buffer, boiled in sample buffer, and resolved by SDS-PAGE for immunoblot experiments.

\section{Results}

\section{Antigen and antibody preparation}

Mice were immunized with the high-molecular-weight glycoproteins of PC12 cells prepared as described (Materials and Methods). The preparation contained three major bands of apparent molecular weights 230,180 , and $160 \mathrm{kDa}$ in SDS-PAGE; two minor bands were also present at about 300 and $80 \mathrm{kDa}$, respectively. Clonal hybridomas were then prepared and screened as described for ability to produce monoclonal antibodies directed against $\mathrm{PC} 12$ cell components. We report here on one of them, designated mAb 1F4. We also retained other clones which secrete immunoglobulins that neither stain $\mathrm{PCl} 2$ cells nor bind to $\mathrm{PC} 12$ proteins in biochemical assays. One such, $\mathrm{mAb} 105$, was routinely used as a control in the experiments reported here. Other controls included no antibody (PBS control), and $\mathrm{mAb}$ 1 F4 preabsorbed with live PC12 cells.

Culture supernatant from IF4 hybridomas, after 30 -fold concentration by ammonium sulfate precipitation, produces a single precipitation line opposite rabbit anti-mouse IgM in an Ouchterlony assay. It does not react with anti-mouse IgG1, IgG2a, $\operatorname{IgG} 2 \mathrm{~b}, \operatorname{IgG} 3$, or IgA. However, the antibody binds to protein A-Sepharose at $\mathrm{pH} 7.4$ and elutes at low $\mathrm{pH}$. We conclude that the $\mathrm{mAb}$ is an IgM with an unusual affinity for protein A (Ey et al., 1978). The antibody has been produced and used as a constituent of culture supernatant, as ascites fluid, and as IgM prepared from either supernatant or ascites fluid. Aside from differences in titer, all three preparations yield similar results.

\section{Staining of PC12 cells and complement-mediated cytotoxicity}

Monoclonal 1F4 produces a bright "rim" staining of fixed PC12 cells in a standard immunofluorescence protocol (Fig. 1, $A-C$ ). One can often see a "skirt" of fluorescent material surrounding the cell body. This probably represents cell membrane flattened down and closely apposed to the surface of the culture dish. Staining is not seen if the $\mathrm{mAb}$ is omitted, replaced by a control mAb from the same fusion (Fig. $1, G, H$ ), or twice preabsorbed with equal volumes of live PC12 cells (Fig. 1, I, J).

PC12 cells exposed to the antibody while living (that is, before fixation) show the same staining pattern (Fig. 1, $C-E$ ). On the other hand, if the cells are allowed to survive $2-4 \mathrm{hr}$ after mAb is introduced into the culture medium for $30 \mathrm{~min}$ and then washed out, they exhibit a "patchy" staining pattern (Fig. $1 F$ ). Patching is not evident within $30 \mathrm{~min}$ of washout. These data are consistent with the interpretation that $\mathrm{mAb} 1 \mathrm{~F} 4$ binds to an antigen on the surface of $\mathrm{PC} 12$ cells-since antibody has access to antigen while the cell is alive and intact-and that live cells will "patch" or "cap" the antigen when it is bound (and presumably partially crosslinked) by the IgM.

After PC1 2 cells differentiate neuronally in response to NGF, the soma and neurites are both stained by mAb 1F4 (Fig. 1, D, $E)$; growth cones are also fluorescent (Fig. $1 E$, inset). This is true whether or not the cells are fixed before exposure to the antibody. There are no gross differences in the staining intensity on soma and neurites.

Immunofluorescent staining of live PC12 cells suggests that at least some of the antigen recognized by the $\mathrm{mAb}$ is a surface component. The same pretreatments used for tissue staining (see below)-preincubation in PBS at pH 6.0, followed by hyaluronidase-have no effect on the surface staining of PC12 cell cultures. It must be noted, however, that our data do not exclude 

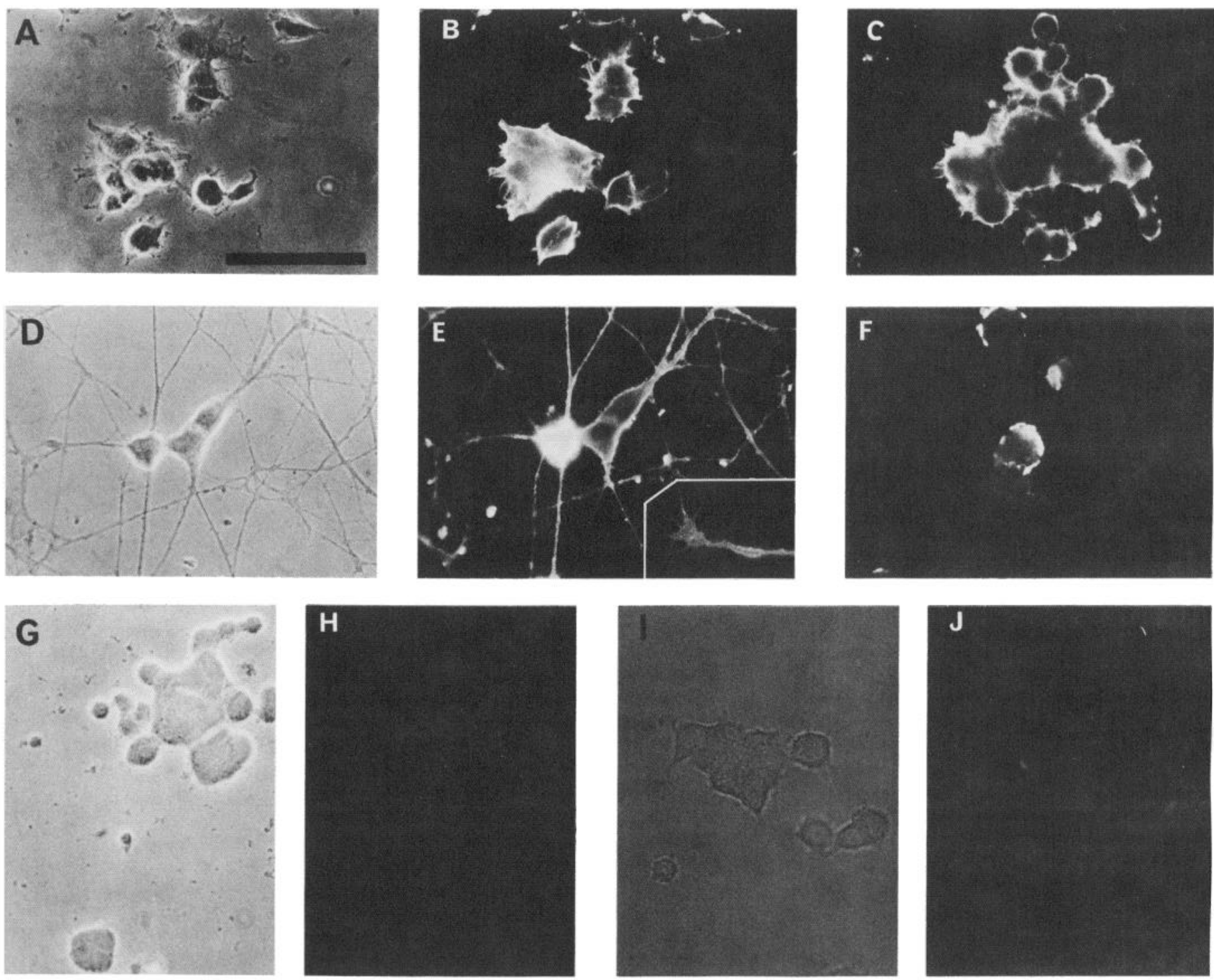

Figure 1. Staining of PC12 Cells. A, B, PC12 cells stained with mAb 1F4 (ascites, 1:100) after fixation with 4\% paraformaldehyde in PBS. Note the "skirts" of membrane around cells which are visualized with the antibody. $A$, Phase image. $B$, Fluorescence. $C, \mathrm{PC} 12$ cells stained with mAb 1F4 (ascites, 1:100) prior to fixation. $D, E$, PC12 cells neuronally differentiated after $14 \mathrm{~d}$ of treatment with NGF and stained (ascites, 1:100) prior to fixation. Note staining of cell bodies and neurites. $D$, Phase image. $E$, Fluorescence. Inset: A growth cone, shown at higher power. This photograph comes from a culture pretreated with PBS at $\mathrm{pH} 6.0$ and hyaluronidase before staining. $F$, PC12 cells were exposed to mAb $1 \mathrm{~F} 4$ (ascites, $1: 100$ ) for $30 \mathrm{~min}$. They were then washed $3 \times 5 \mathrm{~min}$ with PBS and incubated for $2 \mathrm{hr}$ with fresh medium at $37^{\circ} \mathrm{C}$, at which time they were washed, fixed, and stained with second antibody. Note patchy incomplete rim staining, which contrasts with the images seen in $B$ and $C$. $G, H$, PC12 cells stained with control $\mathrm{mAb}$ (ascites, 1:100) after fixation. $G$, Phase image. $H$, Fluorescence. Note absence of staining. The fluorescence exposure parameters are the same as for image $B . I, J$, PC12 cells stained (after fixation) with mAb 1F4 (ascites, 1:50) that has been twice absorbed with live PC12 cells. $I$, Phase. $J$, Fluorescence. Fluorescence exposure parameters are the same as for $B$; note almost complete lack of staining. Scale $\operatorname{bar}(A-J), 50 \mu \mathrm{m}$.

some antibody binding to intracellular components as well, once cells have been permeabilized by fixation.

Further evidence of surface binding is provided by the ability of the mAb to bring about complement-mediated cytolysis of PC12 cells. Within 15 min of exposure to medium containing $10 \%$ guinea pig complement and $10 \% 1 \mathrm{~F} 4$ ascites fluid, individual PC12 cells are lysed and floating, or at least phase-dark. Cells in large clumps survive longer, perhaps because they are protected from antibody and complement by dead cells. Within $30 \mathrm{~min}$, even the majority of cells in clumps are killed. On the other hand, $20 \%$ complement or $20 \% 1 \mathrm{~F} 4$ ascites fluid is ineffective when applied separately, even for periods of $2 \mathrm{hr}$ and more. Exposure to medium with $10 \%$ complement and $10 \%$ ascites fluid from control hybridoma 105 is also without effect.
The killing is therefore due to complement-mediated lysis rather than to nonspecific effects.

\section{Staining of brain tissue}

Sections of mouse and rat brain incubated with mAb 1F4 exhibit a characteristic immunostaining pattern (Fig. 2). The pattern is similar whether binding is visualized by second-antibody fluorescence or immunoperoxidase reaction. It is important to note that successful staining requires pretreatment of the tissue with low $\mathrm{pH}$ and hyaluronidase (see Materials and Methods), although cells in culture can be stained without any pretreatments. This may be because the mAb, which is an IgM and therefore very bulky, does not penetrate tissue well unless the extracellular matrix is "thinned out" by the pretreatments, which would be 

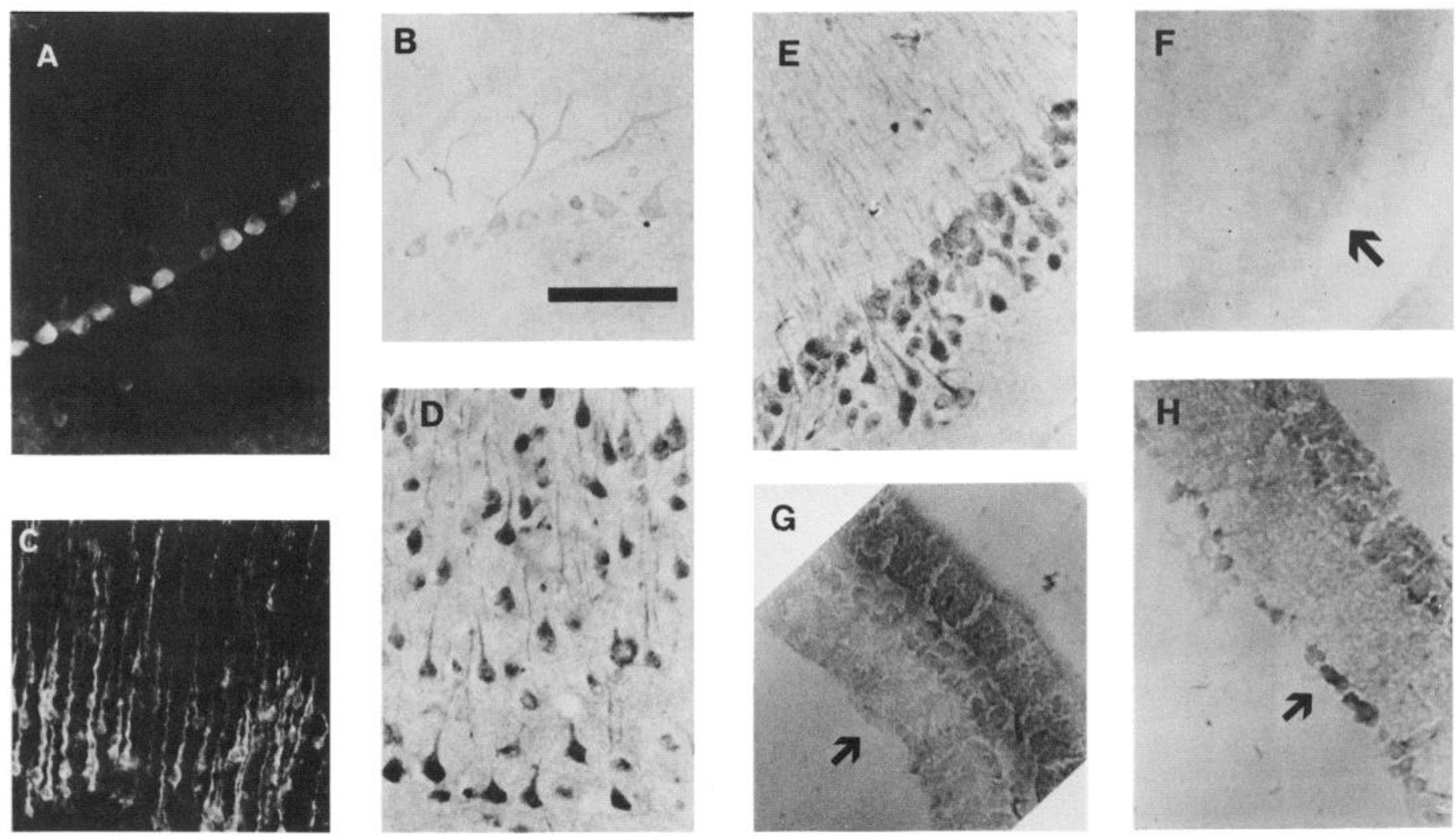

Figure 2. Staining of brain sections. $A, 20 \mu \mathrm{m}$ frozen section of mouse cerebellum, stained with mAb 1F4 ascites fluid at 1:200 dilution and fluorescence visualization. Purkinje cells are stained, other cells are not. Sections incubated with control mAb at the same dilution do not show staining. $B, 50 \mu \mathrm{m}$ Vibratome section of mouse cerebellum, HRP visualization. Note staining of Purkinje cell bodies and dendrites. Ascites fluid, $1: 100$. $C, 20 \mu \mathrm{m}$ frozen section from mouse cerebral cortex, stained with ascites fluid at 1:200 dilution and fluorescence visualization. Note that most stained cells have obvious apical dendrites. $D, 50 \mu \mathrm{m}$ Vibratome section of cerebral cortex, stained with 1:100 ascites fluid and HRP visualization. As in $C$, pyramidal cells are stained. Apical dendrites are visible, but not basal dendrites. No staining is seen in control sections incubated with PBS, control monoclonal, or absorbed mAb 1F4. E. Hippocampus, $50 \mu \mathrm{m}$ horizontal Vibratome section stained with ascites fluid at 1:100 and HRP visualization. Pyramidal cells of the CA1 region are stained; apical dendrites can be seen, cut obliquely. $F$, Control staining of hippocampus. Control mAb 105 ascites fluid diluted 1:100, followed by HRP visualization. The arrow indicates position of the pyramidal cell layer, oriented the same as in $E$ : from lower left to upper right. This photograph is typical of control staining in brain. MAb $1 \mathrm{~F} 4 \mathrm{IgM}$ preabsorbed with live PC12 cells is similarly negative for staining in all brain regions. $G$, Control staining (with absorbed IgM) of mouse retina ( $20 \mu \mathrm{m}$ frozen section processed for HRP). The arrow points to unstained ganglion cell layer; compare to $H$. $H$, Retina stained with mAb $1 \mathrm{~F} 4 \mathrm{IgM}$ at $0.01 \mathrm{mg} /$ $\mathrm{ml}$ and processed for HRP. The arrow points to stained ganglion cells, while other retinal layers resemble control. Scale bars $(A-C, G$ and $H), 100$ $\mu \mathrm{m} ;(D-F), 50 \mu \mathrm{m}$.

Figure 3. Laminar distribution of staining in cerebral cortex. $A, 50 \mu \mathrm{m}$ Vibratome section of adult mouse cerebreal cortex, stained with mAb $1 \mathrm{~F} 4$ and visualized with peroxidase. The arrow points to layer IV, which has fewer stained cells than the more superficial and deeper layers. Compare with $B$. $B$, The adjacent section was stained with antibody, developed with peroxidase, and then counterstained with cresyl violet. Note that many cells can now be seen, especially in layer IV (arrow), which did not react with antibody; these are presumably mostly stellate cells. The large blood vessel provides a landmark useful in comparing the two sections. Scale bar, $100 \mu \mathrm{m}$.

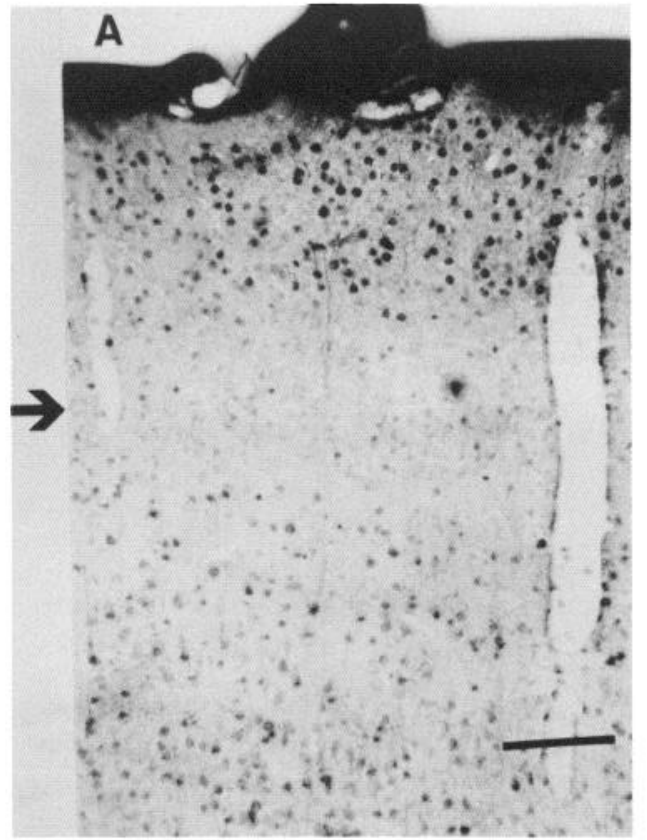

B

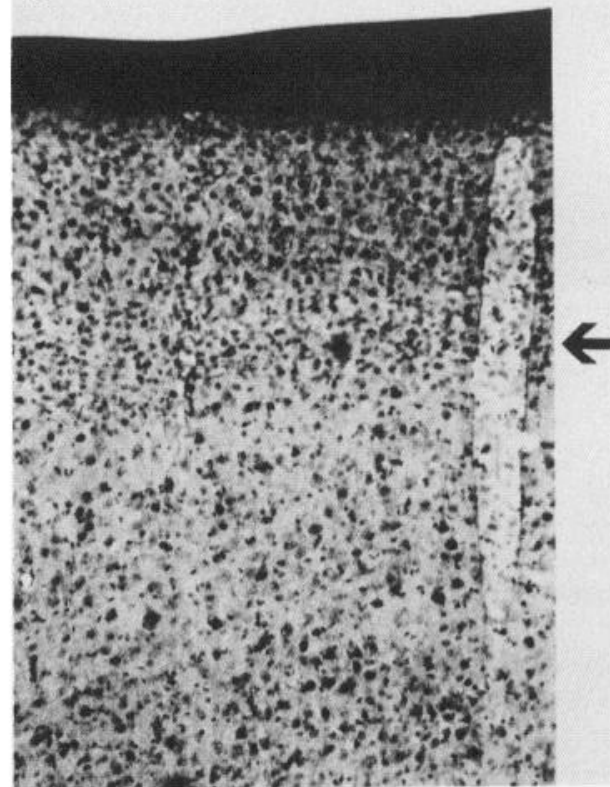


expected to remove some sialic acid residues (Gottschalk and Tuppy, 1972) and hyaluronic acid. These pretreatments do not alter the staining seen in cultured cells.

In cerebellum, Purkinje cells bind the antibody. As can be seen in Figure 2, $A, B$, the soma and proximal dendrite are well stained, but little color development is seen in the molecular layer, although it is a dense feltwork containing many fine branchlets of the Purkinje dendrites. It is also noteworthy that the granule cells, which are the overwhelming majority of neurons in the cerebellar cortex, do not stain. A small number of larger neurons in the granular layer have been seen to stain; these may be the Golgi cells. Finally, the large neurons of all three deep cerebellar nuclei stain.

In the cerebral cortex, many pyramidal cells are stained (Fig. $2, C, D)$. Many of their radially oriented apical dendritic trunks are visible when the plane of section is appropriate; however, as in cerebellum, fine dendritic branches do not appear to be stained. Despite the intense staining of apical dendrites, the finer basal dendritic arbors are not evident, even near the soma. Axons are also not visualized, whether in cerebral cortex, other parts of the brain, or fiber tracts.

No recognizable stellate cells can be seen to stain. Although somata without obvious apical dendrites can be found, this could be due to the orientation of the plane of section or to the failure of antibody to bind to the trunk dendrites of some pyramidal cells. We have never observed cells with oblique or stellate dendritic staining. The conclusion that staining is restricted to pyramidal cells is reinforced by cresyl violet-counterstained sections, which have a large number of cells stained with cresyl violet but not with HRP, in layer IV, while HRPstained pyramidal cells are common in the superficial and deeper layers (Fig. 3). Layer IV is dominated by stellate cells, unlike layers II, III, V, and VI (Peters and Jones, 1984).

Pyramidal cells of the hippocampal gyrus are well stained by the antibody (Fig. 2E). Again, apical dendritic trunks take up stain, while basal dendritic arbors and fine branchlets do not. Granule cells of the stratum oriens are not seen. On the other hand the cells of the dentate gyrus, which project back to the hippocampus proper, stain well. In through-sections of complete mouse brain we have observed large, stained cells in all brain structures and nuclei; but counterstaining with cresyl violet indicates that not all neurons are stained. In order to substantiate our interpretation of the kind of selectivity displayed by the antibody, sections of neural retina were prepared. Here, we find that only the ganglion cells stain specifically, while the other layers appear equivalent to controls (Fig. 2, $G, H$ ).

The staining pattern just described is not seen when control monoclonal antibodies are used at the same dilution; this is illustrated for hippocampus in Figure $2 F$ and for retina in Figure $2 G$. Control sections for other brain regions, including cortex and cerebellum (not shown), are similarly blank. Furthermore, $\mathrm{mAb} 1 \mathrm{~F} 4$, after preabsorption with live PC12 cells, also yields no staining of brain. This demonstrates that our reagent does in fact have a single activity, and that the staining can be absorbed out by the surface antigen on PC12 cells. Finally, antibodies of different specificities that are routinely used in our laboratories (tubulin, microtubule-associated proteins, neurofilament, glial filament, etc.) never produce this pattern.

We have seen no evidence of glial staining in brain sections. Also, no staining above background is seen in sections of rat heart, kidney, liver, or adrenal gland (Fig. 4). Other tissues tested for staining, which were also negative, include lung, spleen, and testis.

The staining of neurons in tissue does not show a "rim"-like staining pattern such as is seen with $\mathrm{PC} 12$ cells. Instead, the cell body and trunk dendrite appear, at the light-microscopic level, to be filled with stain (Fig. 2). In one experiment, electronmicroscopic thin sections of HRP-stained pyramidal cells from
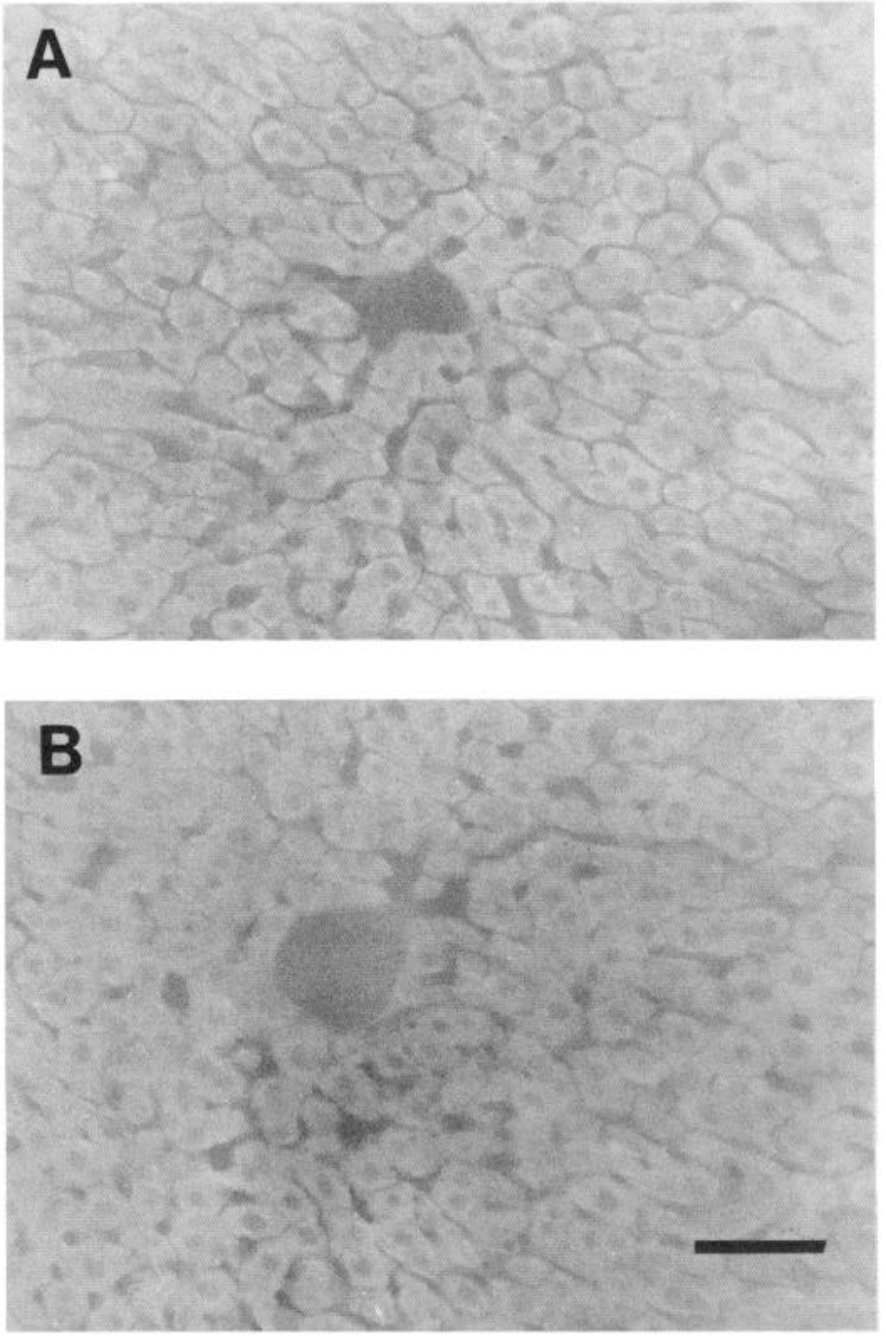

Figure 4. MAb 1F4 does not stain nonneural tissues. $A, B$, Liver. 20 $\mu \mathrm{m}$ frozen sections processed for fluorescence. The photographs are overexposed to reveal tissue structure, but the same exposure parameters are used in control and experimental sections. $A$, Control antibody; $B$, $\mathrm{mAb}$ 1F4. Other tissues tested for staining, all of which were negative, include heart, kidney, adrenal, lung, spleen, and testis. Scale bar, 50 $\mu \mathrm{m}$.

mouse cerebral cortex were made. The reaction product is seen in the cytoplasm of cell body and trunk dendrite, but not in the nucleus. In particular, membranous profiles of intracellular organelles such as endoplasmic reticulum and mitochondria appear darkened by the stain (Fig. 5). However, there is also diffuse stain throughout the cytoplasm and perhaps some deposition on the plasma membrane, although we cannot say whether it is on the inner or outer surface. Precise localization of HRP reaction product is often unreliable, but these observations suggest that, when applied to brain tissue, the antibody binds mostly to antigen inside the cell, and that the antigen is restricted to the cell soma and proximal dendrite. We have conducted biochemical and culture experiments, using neural tissue, to further investigate the nature and distribution of the brain antigen(s) recognized by $\mathrm{mAb} 1 \mathrm{~F} 4$.

\section{Staining and cytotoxicity in neuronal cultures}

Dissociated cell cultures from E15 and E16 rat cerebral cortex were prepared as in Materials and Methods. In most experiments, but not all, some cells can be found that are stained by $\mathrm{mAb} 1 \mathrm{~F} 4$ after fixation. The occasional failure to find stained cells is probably due to slight variations in culture conditions, 


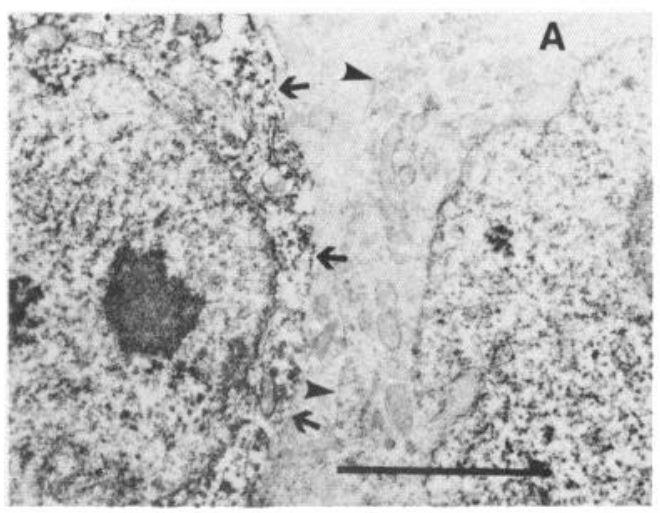

Figure 5. Electron-microscopic immunohistochemistry. A, Two adjacent cells, one stained (arrows) and the other unstained (arrowheads). Note that the cytoplasm of the cell on the left contains reaction product and that of the cell on the right does not, although the nuclei are similar in density. The cytoplasm of the unstained cell is comparable to the surrounding tissue in density. $B$, High-power view of a stained cell. Prominent stained profiles of endoplasmic reticulum are visible. $C$, A third stained cell, seen at lower power. Note stain around profiles of endoplasmic reticulum and mitochondria, but also diffusely in cytoplasm. Scale bars: $(A) 2 \mu \mathrm{m}$; (B) 0.5 $\mu \mathrm{m} ;(C) 2.5 \mu \mathrm{m}$.
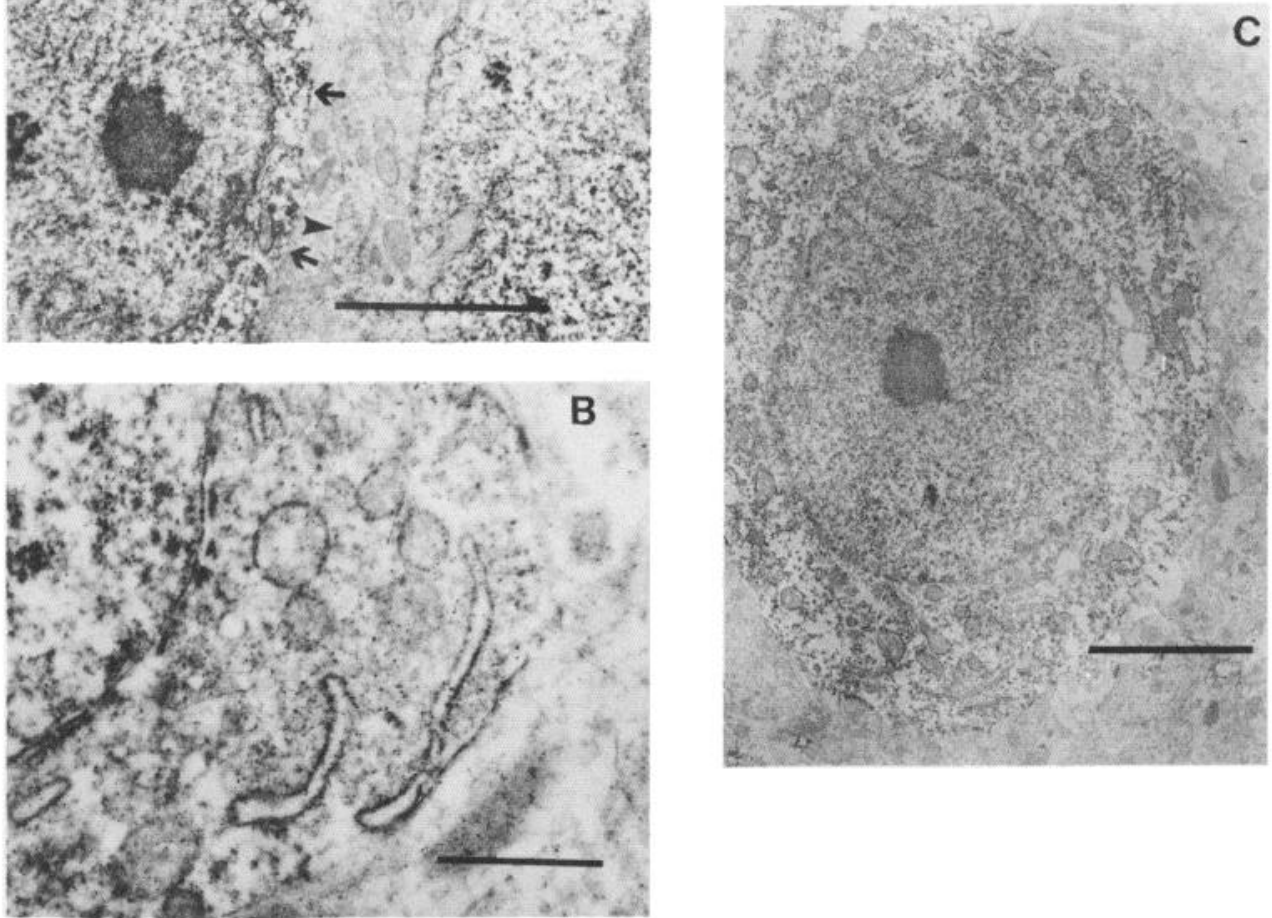

which differentially affect the survival of the relevant cells. Stained cells can be seen using either second-antibody fluorescence or immunoperoxidase visualization (Fig. $6, A, B, D-F$ ). The fraction of cells stained, however, is small (much less than $1 \%$ ). Stained cells appear to be neurons, and are among the largest cells present. Considering the staining pattern seen in tissue sections, it seems likely that the stained cells represent young pyramidal cells.

However, if cultures are incubated with $\mathrm{mAb} 1 \mathrm{~F} 4$ before fixation (i.e., while living), stained cells cannot be found (Fig. 6, $G, H)$. The same is true if cultures are fixed but incubated with control antibodies (Fig. $6 \mathrm{C}$ ), or with $\mathrm{mAb} 1 \mathrm{~F} 4$ preabsorbed with live PC12 cells. The failure of the antibody to stain living brain cells contrasts with its performance on live PC12 cells, and suggests that it recognizes mainly an internal antigen in the large brain cells, although it reacts strongly with a surface antigen on PC1 2 cells. A more uniform population of neurons is obtained from dissociated cell cultures of newborn rat superior cervical ganglia (SCG). These cells are known to have a set of cell-surface high-molecular-weight glycoproteins similar to PC12 cells, with the exception of the $160 \mathrm{kDa}$ species, which does not appear to be present (Lee et al., 1981; Richter-Landsberg et al., 1984). In this case, it is clear that the antibody stains SCG neurons when they are fixed (Fig. 7, $A, B$ ), but not if they are incubated before fixation (Fig. $7, E, F$ ) or with $\mathrm{mAb} 1 \mathrm{~F} 4$ preabsorbed with $\mathrm{PC} 12$ cells (Fig. 7, $C, D$ ). Staining of neurites is slightly above control levels but much weaker than the staining of the soma. Schwann cells and fibroblasts present in these cultures do not stain. Sections of newborn rat SCG exhibit staining as well.

Incubation with the same concentrations of mAb 1F4 and complement used in the PC12 cytotoxicity experiments described above does not affect either cerebral cortex or SCG cultures. No cell death was seen, either by simple inspection or after staining with trypan blue. In cortical cultures, the percentage of stained cells is so low that cell death might not be detected even if it were occurring; but in SCG cultures, the ganglion cells, all of which stain with the antibody when fixed, are numerous and easily recognizable. They are not affected by antibody and complement, and exclude trypan blue even after hours of exposure. In previous experiments using rabbit antisera against the NILE glycoprotein, it has been possible to obtain complement-mediated cytolysis of cultured SCG neurons (Salton et al., 1983a, b). These culture experiments, therefore, suggest that the surface antigen recognized by mAb 1F4 on PC12 cells is either not present, or only weakly present, on the surfaces of embryonic brain cells and SCG cells from newborn rats. This is consistent with prior evidence that the $160 \mathrm{kDa} P C 12$ antigen cannot be detected in brain (Lee et al., 1981). However, some antigen recognized by the antibody must be present in the types of neurons that can be stained when fixed.

\section{Biochemical identification of PC12 antigen(s) recognized by $m A b \quad 1 F 4$}

MAb 1F4 specifically recognizes proteins of about 160 and 95 $\mathrm{kDa}$ when presented with an SDS extract of PC12 cells in Western immunoblot experiments (Fig. 8A). These bands do not appear when no first antibody is used (PBS control), or in the case of a control monoclonal. Antibody preabsorbed with live PC1 2 cells also does not react. Nonspecific bands, corresponding to major proteins of the preparation that react directly with the second and third reagents used in the visualization procedure, are seen; but these appear in both control and experimental strips, while the 160 and $95 \mathrm{kDa}$ bands are seen only in strips incubated with $\mathrm{mAb} 1 \mathrm{~F} 4$. Since the $\mathrm{mAb}$ was produced against immunogen containing a glycoprotein of $160 \mathrm{kDa}$, we immunoblotted against a preparation of $\mathrm{PC} 12$ glycoproteins made by WGA-affinity chromatography (without HPLC size fractionation). The $160 \mathrm{kDa}$ band appears specifically in experimental lanes, but not in controls (Fig. $8 B$ ). It is noteworthy that material in the $80-90 \mathrm{kDa}$ range is also specifically immunoblotted; this 

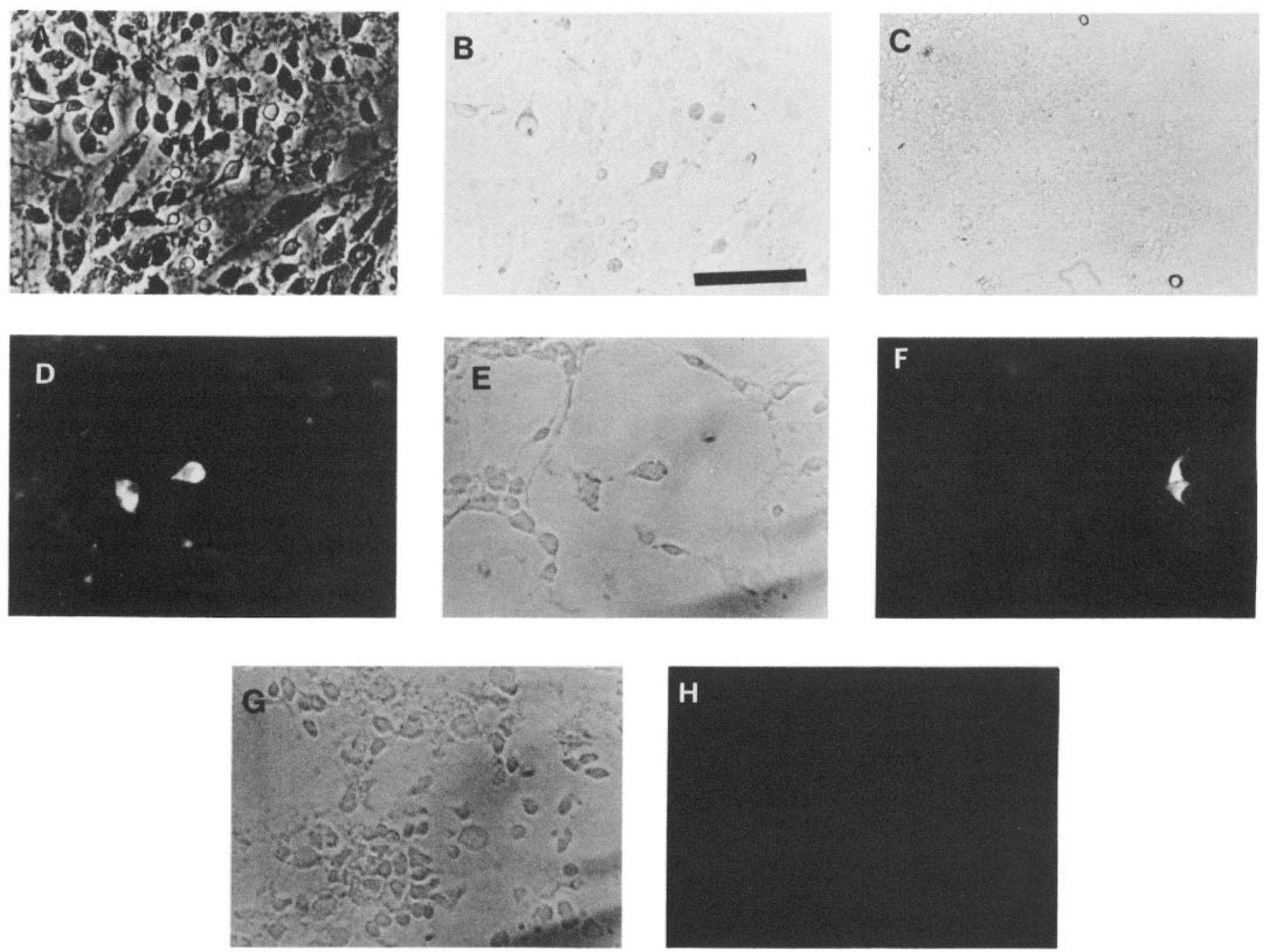

Figure 6. Dissociated cell cultures from newborn rat cerebral cortex. $A, B$, Phase and fluorescent images of a microwell culture of cerebral cortex, fixed and then stained with mAb 1F4 (ascites, 1:100) and HRP visualization. A few stained cells are seen in $B$; the phase image in $A$ shows numerous unstained cells, including flat cells that cannot be made out in the brightfield image. $C$, Brightfield image of a microwell culture fixed and then stained with control $\mathrm{mAb}$ ascites fluid at the same dilution used in $B$; HRP visualization. No stained cells are seen in this field or anywhere in such cultures. $D-F$, Cortical dissociates fixed, stained with $\mathrm{mAb} 1 \mathrm{~F} 4$ (ascites, 1:100), and processed for fluorescence. Note the few large, bright cells. $E$ is a phase image corresponding to the fluorescent image in $D . F$ is a fluorescent image of a different field. $G, H$, Cortical dissociate culture exposed to mAb 1F4 (ascites, 1:100) prior to fixation. $G$, Phase. $H$, Fluorescence. The fluorescence exposure parameters are the same as those used to produce fluorescent images $D$ and $F$. No stained cells were found anywhere on coverslips processed in this way. Scale bars $(A$ and $B, D-H): 50$ $\mu \mathrm{m} ;(C) 100 \mu \mathrm{m}$.

could be the product of degradation of either of the bands noted above, since the opportunity for degradation is much greater than when cells are directly solubilized and electrophoresed. No nonspecific bands are seen in such experiments because major proteins have been reduced through the lectin chromatography step.

In the case of antibody recognition of glycoproteins, one would like to know whether the antibody is directed against sugar residues or part of the apoprotein. To address this question, we grew PC12 cells in the presence of tunicamycin (an inhibitor of glycosylation) at $5 \mu \mathrm{g} / \mathrm{ml}$ for $72 \mathrm{hr}$. This treatment inhibits incorporation of ${ }^{3} \mathrm{H}$-fucose into TCA-precipitable material by 90 $95 \%$. Western immunoblots show that specific immunoreactivity is retained under these conditions (Fig. $8 A$, right lane). In particular, the $95 \mathrm{kDa}$ band remains immunoreactive, with little or no change in mobility, while the $160 \mathrm{kDa}$ band is shifted to lower molecular weight. Two bands, at 130 and $115 \mathrm{kDa}$, are visible in the experiment illustrated; in a second trial, only the $115 \mathrm{kDa}$ band was seen. It is important to note that since the
$95 \mathrm{kDa}$ band appears stronger in the tunicamycin-treated cells, it is possible that some of the $160 \mathrm{kDa}$ material could be shifted to this molecular weight as well.

Immunoprecipitation represents an alternative approach to the problem of identifying the antigen to which an antibody binds. The 1F4 monoclonal gives a weak and inconsistent result in such experiments, but in four trials two faint bands were specifically precipitated from extracts of PC12 cells labeled with radioactive fucose. On SDS-PAGE, one of these bands runs directly opposite the $160 \mathrm{kDa}$ band in the whole cell extract from which the precipitate was made, while the other is a diffuse band running in the $95 \mathrm{kDa}$ region of the gel. These results are consistent with the more reliable immunoblot experiments already described.

\section{Biochemical identification of antigen(s) recognized in brain}

In order to pursue the identification of the antigen recognized by $\mathrm{mAb} 1 \mathrm{~F} 4$ in brain, immunoblot experiments were carried 

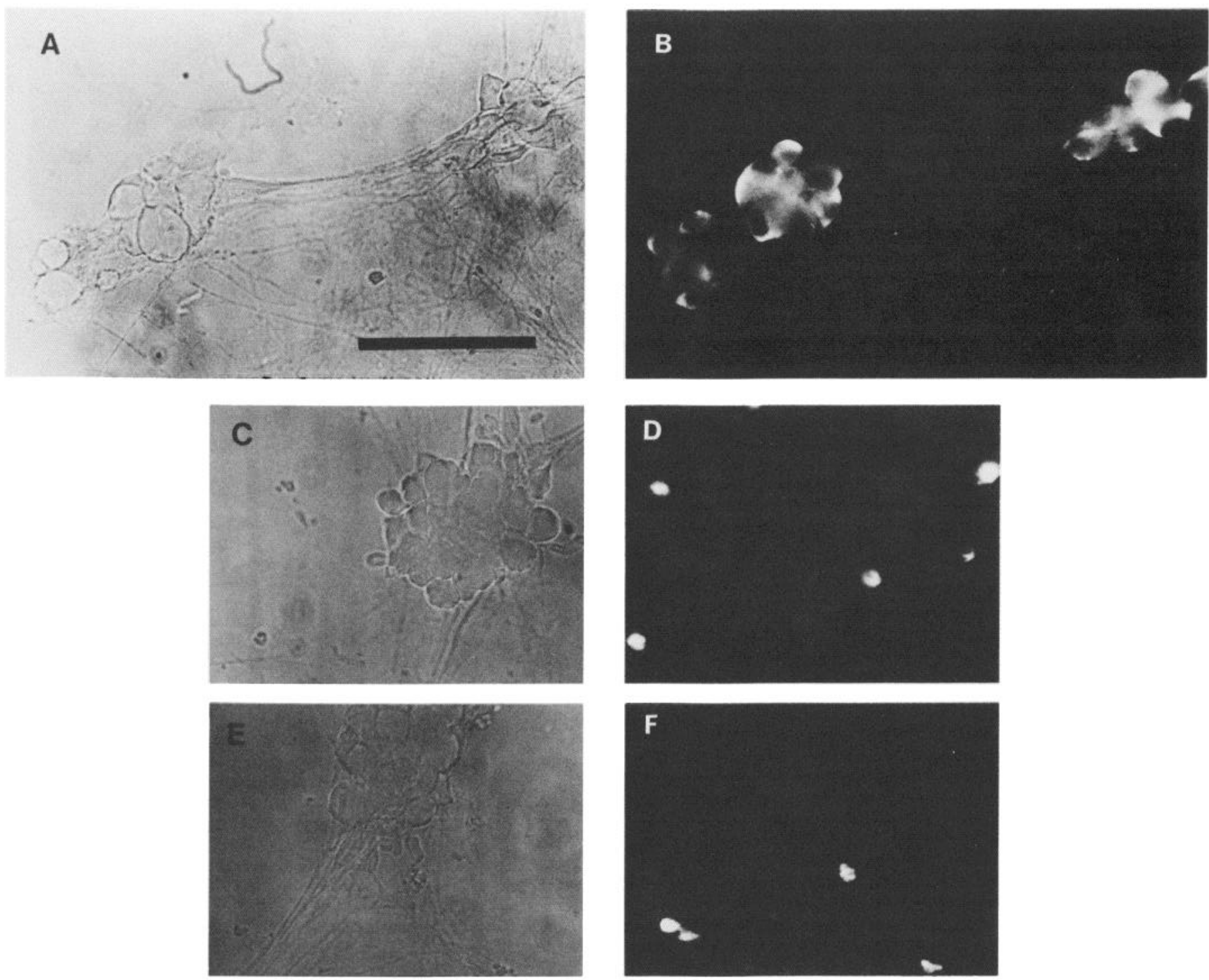

Figure 7. Staining of dissociated cell cultures from rat SCG. A, B, Dissociated SCG neurons stained after fixation with mAb 1F4 (ascites, 1:100). $A$, Phase image. $B$, Fluorescence. Note "intracellular" appearance of the stain. Neurites, out of focus in this image, are slightly brighter than in controls, but much darker than the somas. $C, D$, SCG neurons stained after fixation with $\mathrm{mAb} 1 \mathrm{~F} 4$ ascites fluid that had been previously absorbed with live PC12 cells and diluted 1:50. $C$, Phase. $D$, Fluorescence. Note lack of staining as compared with $B$; this indicates that the activity that binds internally to the SCG cell has been absorbed out by antigen on the surface of live PC1 2 cells. $E, F$, SCG neurons exposed to mAb $1 \mathrm{~F} 4$ ascites at 1:100 while living, then fixed and incubated with fluorescent second antibody. $E$, Phase. $F$, Fluorescence. The mAb does not bind to these cells unless they have been permeabilized by fixation. Scale bar $(A-F), 50 \mu \mathrm{m}$.

out using protein extracts from whole adult rat brain and from cultures of embryonic cerebral cortex. These attempts were unsuccessful, perhaps because such extracts are too complex and contain relatively little of the material recognized by the antibody. To enrich for it, we used glycoprotein preparations made from crude subfractions of rat brain.

Crude microsomal fractions of rat brain solubilized in deoxycholate and affinity-chromatographed on a column of WGASepharose (as above) yield a glycoprotein preparation in which bands of 130 and $95 \mathrm{kDa}$ are specifically recognized by $\mathrm{mAb}$ 1 F4 when immunoblotted (Fig. 7D). Neither control mAb nor $\mathrm{mAb} 1 \mathrm{~F} 4$ preabsorbed with live $\mathrm{PC} 12$ cells will react with these bands. Other fractions (the 12,000 gm pellet and soluble fraction) do not yield immunoreactive material. These experiments confirm that glycoprotein that is specifically recognized by $\mathrm{mAb}$ $1 \mathrm{~F} 4$ does exist in rodent brain, and that this material is enriched in a crude microsomal fraction prepared from whole brain.

\section{Discussion}

We have reported on the properties of a monoclonal antibody produced against a mixture of high-molecular-weight glycoproteins from PC12 cells. Previous studies on surface proteins of PC1 2 cells utilized rabbit or guinea pig antisera prepared against whole PC1 2 cells (Lee et al., 1980a, b, 1981) or SDS-denatured glycoprotein cut out of gels (Salton et al., 1983a, b). Immunoabsorption studies (Lee et al., 1981) indicated that the prominent fucosylated glycoproteins at 230,180 and $140 \mathrm{kDa}$ are found in brain as well as PC12 cells (Lee et al., 1981). The 230 $\mathrm{kDa}$ (NILE) protein, in particular, appears to be a general marker of neurons, and its biochemistry has been well studied in PC12 cells, sympathetic neurons, and brain (Margolis et al., 1983; Richter-Landsberg et al., 1984; Salton et al., 1983a, b; Sweadner, $1983 a, b)$. Reports have recently appeared (Stallcup and Beasley, 1985; Stallcup et al., 1985) dealing with the localization of this 


\section{A}
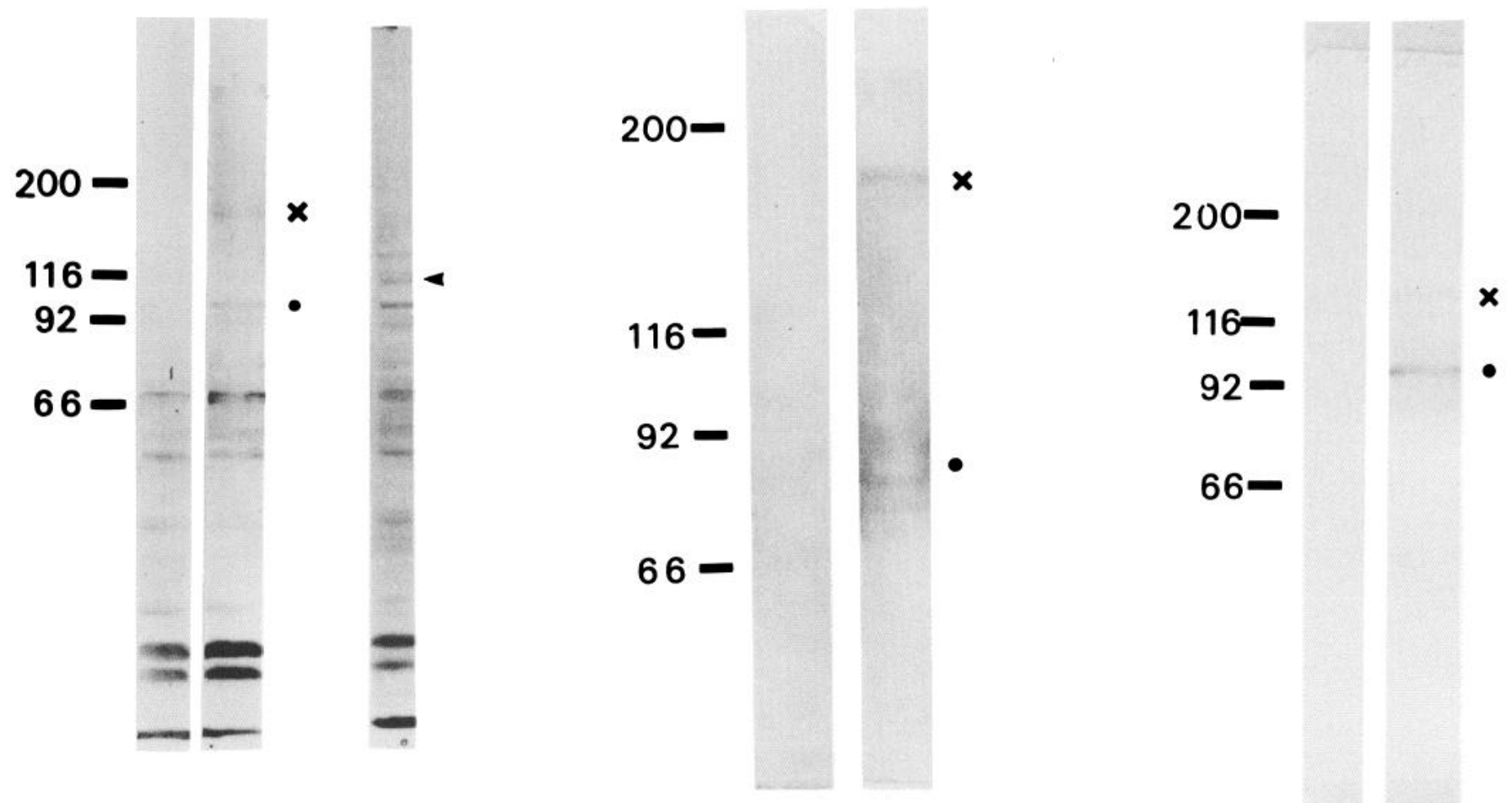

Figure 8. Western immunoblots. A, Whole SDS extract of PC12 cells, blotted with control mAb ascites at 1:100 (left), and with mAb 1F4 at the same dilution (center). Although many bands appear nonspecifically in control and experimental lanes, bands not present in control at $M, 160 \mathrm{kDa}$ (cross) and $95 \mathrm{kDa}($ dot $)$ are seen in the experimental lane. Similar results were obtained in 12 independent experiments, although the bands are not always of equal prominence. The right lane shows cells grown for $3 \mathrm{~d}$ in the presence of tunicamycin (Methods). The $160 \mathrm{kDa}$ band is not seen, and bands are visible at 130 and $115 \mathrm{kDa}$ (arrowhead) that never appear in blots of untreated cells. The $95 \mathrm{kDa}$ band remains specifically immunoreactive and is shifted little if at all in mobility. (The bars and numbers at left in this and other panels indicate the positions of molecular weight standards, given as $M_{r} \times 10^{-3}$.) $B$, Glycoproteins prepared from solubilized whole PC12 cells and immunoblotted. The right lane shows

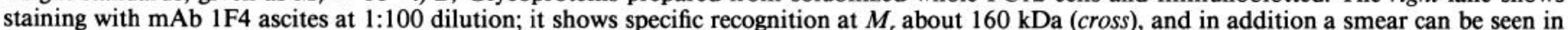
the $80-90 \mathrm{kDa}$ range (dot). A control strip (left) incubated with control ascites at the same dilution shows no reaction at all. $C$, Glycoproteins were prepared as described (Methods) from crude microsomal fraction of rat brain and immunoblotted. Specific bands appear in experimental lane (right; $\mathrm{mAb} 1 \mathrm{~F} 4 \mathrm{IgM}$ at $0.01 \mathrm{mg} / \mathrm{ml}$ final dilution) and not when PC12-preabsorbed IF4 IgM is used at the same dilution (left). Control mAb 105 ascites fluid at 1:100 dilution is also negative. The upper band recognized in these brain preparations (cross) migrates at $130 \mathrm{kDa}$, the lower band at $95 \mathrm{kDa}(d o t)$.

antigen in fiber tracts of the brain, and its possible role in fasciculation of neurites in culture.

A fourth species of cell-surface glycoprotein from PC1 2 cells, at $160 \mathrm{kDa}$, has not been detected in either brain or adrenal medulla, and might represent a transformation-associated protein (Lee et al., 1981). The present antibody, mAb 1F4, binds to an exposed component of the $\mathrm{PC} 12$ cell surface, since it can bind to live cells and lyse them in the presence of complement. The evidence from immunoblots and immunoprecipitations indicates that it specifically recognizes a glycoprotein of apparent SDS-PAGE molecular weight of about $160 \mathrm{kDa}$, evidently the same as the species just mentioned. The 1F4 antibody also binds to a $95 \mathrm{kDa}$ protein; this may represent a less glycosylated form of the $160 \mathrm{kDa}$ species or a cross-reacting but distinct molecule (see below).

One particularly interesting result of the present study is the pattern of immunohistochemical staining observed in brain with $\mathrm{mAb} 1 \mathrm{~F} 4$. The positive staining is limited to a subgroup of neurons, and is absent from glia and nonneural tissues. In major cortical structures, where neuronal subtypes can be readily distinguished on the basis of position, morphology, and projection patterns, we can identify the stained cells as the large projection neurons of each structure: pyramidal cells in the cerebral cortex and hippocampus, Purkinje cells of the cerebellum, and ganglion cells of the retina. Also, in many sensory and motor nuclei it is evidently the large cells (presumably the projection neurons) that stain. This result parallels others previously reported in the literature, although it is not clear that any of the earlier studies exactly reproduces the staining pattern yielded by mAb 1F4. Probably the closest parallel is provided by the work of Wood et al. (1982) on a mAb designated CE5, which stains Purkinje cells, pyramidal cells, and other cells believed to be projection neurons in CNS and PNS. The antibody appears to bind both internally and externally to target neurons. Interestingly, the antibody recognizes an antigen on the surface of the parasite $T$. cruzei, which is responsible for Chagas' disease. The brain antigens recognized in immunoblots are faster-migrating than the ones we have detected, but we note that a $130 \mathrm{kDa}$ antigen from the parasite itself is detected.

Other studies have produced staining with less close similarities to the pattern reported here. Hockfield and McKay (1983) have reported staining, with a monoclonal antibody, Cat-301, somata and proximal dendrites of projection neurons in anterior horn of spinal cord. In cortex, this antibody is said to stain pyramidal and other cells; but Purkinje cells are not stained. The antigen has not been identified biochemically, but it appears 
to be largely extracellular. Levitt (1984) has produced a monoclonal which appears to be directed against large neurons of the limbic system, including hippocampal pyramids. The BSP-3 monoclonal of Hirn et al. (1982) reacts with a glycoprotein of $48 \mathrm{kDa}$; in staining experiments, it binds to both neurons and glia, but electron-microscopic evidence indicates that it can bind to the surfaces of some cells and to cytoplasmic components of others. A number of reports have appeared that describe antibodies binding more or less specifically to Purkinje cells (de Blas, 1984; Garson et al., 1982; Reeber et al., 1981; Weber and Schachner, 1982; Woodhams et al., 1979), the significance of which, with respect to the present work, is hard to assess. There are a few cases in which the functions of neuronal type-specific antigens have been identified, notably the demonstration by Lohmann et al. (1981) that cyclic GMP-dependent protein kinase is restricted, among neurons, to the Purkinje cells.

The function of the antigen detected in large projection neurons stained by $\mathrm{mAb} 1 \mathrm{~F} 4$ has not been determined in this study, but we can characterize it to some extent. First, the brain antigen is predominantly intracellular. This is indicated by a number of the results reported above: the appearance of stained cells in tissue; the staining of fixed but not live neurons in culture; and the failure of the $\mathrm{mAb}$ to lyse cultured neurons in the presence of complement. Second, our immunoblots against glycoproteins made from subcellular fractions of brain indicate that there are CNS molecules of 130 and $95 \mathrm{kDa}$ recognized by the antibody, and that these are found only in the crude microsomal fraction. They may, therefore, be components of endoplasmic reticulum. This possibility is also raised by the indications from immunohistochemical experiments that bound antibody in brain cells is restricted to the soma and nearby trunk dendrites-regions containing endoplasmic reticulum - and that on the EM level there is noticeable stain deposition on ER profiles. However, none of our experiments allow us to conclusively identify the cellular compartment or organelle with which the antigens are associated.

It is not possible at this time to say definitely that the brain and $\mathrm{PC} 12$ antigens are related, but there are reasons to think that they may be. First, each system contains an antigen of similar electrophoretic mobility $(95 \mathrm{kDa})$, as well as a highermolecular-weight species (PC12: $160 \mathrm{kDa}$; brain: $130 \mathrm{kDa}$ ). Second, although all of these antigens are likely to be glycoproteins (since they bind specifically to WGA), it appears that the antibody is directed against a protein epitope. This is indicated by the retention of immunoreactivity and the shift of the 160 $\mathrm{kDa}$ band to lower molecular weight when incorporation of sugar residues into glycoproteins of $\mathrm{PC} 12$ cells has been largely inhibited by incubation for $3 \mathrm{~d}$ with tunicamycin. The nature of monoclonal antibodies makes it very likely that since $\mathrm{mAb}$ 1F4 appears to react with a protein determinant in the case of one immunoreactive band, it does the same in all.

Because the $95 \mathrm{kDa}$ band also remains immunoreactive in tunicamycin-treated cultures, but does not shift detectably in molecular weight, it may represent a minimally glycosylated (or unglycosylated) protein core shared with the higher-molecularweight species. Of course, one cannot rulc out the possibility that it is a relatively unrelated protein, sharing only the particular determinant recognized by the antibody. In any case, whatever the relation between the $95 \mathrm{kDa}$ band and the highermolecular-weight species seen in each system, the observation that brain and PC1295 kDa aproteins share both a common epitope and the same electrophoretic mobility makes it likely that these antigens, at least, are related. It must be noted that, although it is evident that the antibody binds to the surface of the PC12 cell, and that the $160 \mathrm{kDa}$ glycoprotein is exposed there, we have no reason to exclude the possibility that it may bind to internal components of the cell as well. Our experiments thus allow the possibility that the $95 \mathrm{kDa}$ antigen is an internal component of PC12 cells, as in the brain.
The immunohistochemical staining pattern we have described indicates that a certain antigen (or set of antigens) is shared by large projection neurons in many brain structures, but not by smaller cells, interneurons, or nonneuronal cells. It may be that their common requirements (building extensive dendritic trees to integrate large amounts of local input, and sending long-projection axons to specific targets elsewhere in the nervous system) impose the need for certain common proteins on the major output cells of many different parts of the nervous system. What might such proteins be? They might, for example, be proteins of intracellular membranous organelles associated with the anabolic requirements of producing and supporting long processes-requirements shared, perhaps, by certain transformed cells that are undergoing continuous growth and division.

That the antibody developed and used in the present study, $\mathrm{mAb} 1 \mathrm{~F} 4$, may recognize an antigenic protein species having several forms, differing principally in the extent of glycosylation, is consistent with all the evidence. [There are many precedents for this. For example, the NILE glycoprotein from brain differs from the $\mathrm{PCl} 2$ form by some $15 \mathrm{kDa}$ in SDS-PAGE; this difference has been shown (Salton et al., 1983b) to be due to variable glycosylation.] According to this interpretation, the smaller forms $(95$ and $130 \mathrm{kDa})$ are characteristic of internal membranes of large projection neurons in the brain. In PC12 cells, the 95 $\mathrm{kDa}$ species is present, as well as a larger form (160 kDa), presumably heavily glycosylated, that appears on the surface membrane-perhaps associated with the transformed state. The utility of the clonal PC12 cell line in molecular-genetic as well as biochemical studies may offer further opportunities to investigate these notions.

\section{References}

Akeson, R. L., and S. L. Warren (1984) Detection of a cell surface antigen found on rat peripheral nervous system neurons and multiple glia: Astrocytes, oligodendrocytcs, and Schwann cells. J. Neurosci. Res. 12: 41-57.

Bonner, W. M., and R. A. Laskey (1974) A film detection method for tritium-labeled proteins and nucleic acids in polyacrylamide gels. Eur. J. Biochem. 46: 83-88.

Braun, S. J., K. J. Sweadner, and P. H. Patterson (1981) Neuronal cell surfaces: Distinctive glycoproteins of cultured adrenergic and cholinergic sympathetic neurons. J. Neurosci. 1: 1397-1406.

Buckley, K. M., E. S. Schweitzer, G. P. Miljanisch, L. Cliff-O'Grady, P. D. Kushner, L. F. Reichardt, and R. B. Kelly (1983) A synaptic vesicle antigen is restricted to the junctional region of the presynaptic plasma membrane. Proc. Natl. Acad. Sci. USA 80: 7342-7346.

Celio, M. R., and C. W. Heizmann (1981) Calcium-binding protein parvalbumin as a neuronal marker. Nature 293: 300-302.

Cohen, J., and S. Y. Selvendran (1981) A neuronal cell-surface antigen is found in the central nervous system but not in peripheral neurons. Nature $291: 421-423$.

de Blas, A. (1984) Monoclonal antibodies to specific astroglial and neuronal antigens reveal the cytoarchitecture of the Bergmann glia fibers in the cerebellum. J. Neurosci. 4: 265-273.

Dichter, M. A. (1978) Rat cortical neurons in cell culture: Culture methods, cell morphology, electrophysiology, and synapse formation. Brain Res. 149: 279-293.

Edelman, G. M. (1984) Modulation of cell adhesion during induction, histogenesis, and perinatal development of the nervous system. In Annual Reviews of Neurascience, Vol. 7, pp. 339-377, Annual Reviews, Palo Alto, CA.

Ey, P. L., S. J. Prowse, and C. R. Jenkin (1978) Isolation of pure IgGl, IgG2a, and IgG2b immunoglobulins from mouse serum using protein-A sepharose. Immunochemistry 15: 429-436.

Faissner, A., J. Kruse, J. Nieke, and M. Schachner (1984) Expression of neural cell adhesion molecule $L 1$ during development, in neurological mutants and in the peripheral nervous system. Dev. Brain. Res. 15: 69-82.

Galfre, G., and C. Milstein (1981) Preparation of monoclonal antibodies: Strategies and procedures. In Methods in Enzymology, Vol. 73, H. van Vunakis, ed., pp. 3-46, Academic, New York.

Garson, J. A., P. C. L. Beverly, H. B. Coakham, and E. I. Harper (1982) 
Monoclonal antibodies against human T lymphocytes label Purkinje neurones of many species. Nature 298: 375-377.

Gottschalk, A., and H. Tuppy (1972) Structure of sialic acids and their quantitation. 4.1.3. Isolation and identification. In Glycoproteins: Their Composition, Structure, and Function, 2nd Ed., A. Gottschalk, ed., Vol. 5, BBA Library, Elsevier, New York.

Greene, L. A., and A. S. Tischler (1976) Establishment of a noradrenergic clonal line of rat adrenal pheochromocytoma cells which respond to nerve growth factor. Proc. Natl. Acad. Sci. USA 73: 24242428.

Greene, L. A., and A. S. Tischler (1982) PC12 pheochromocytoma cultures in neurobiological research. In Advances in Cellular Neurobiology, S. Fedoroff and L. Hertz, eds., Academic, New York.

Hatten, M. E., and A. M. Francois (1981) Cell assembly patterns of embryonic and early postnatal mouse cerebellar cells on lectin-derivatized culture substrata. Dev. Biol. 87: 102-113.

Hawkes, R. E. Niday, and A. Matus (1982a) Monoclonal antibodies identify novel neural antigens. Proc. Natl. Acad. Sci. USA 79: 24102414.

Hawkes, R., E. Niday, and A. Matus (1982b) MIT-23: A mitochondrial marker for terminal neuronal differentiation defined by a monoclonal antibody. Cell 28: 253-258.

Heide, K., and II. G. Schwics (1973) Salt fractionation of immunoglobulins. In Handbook of Experimental Immunology, D. M. Weir, ed., Blackwell, Oxford.

Hirn, M., M. Pierres, H. Deagostini-Bazin, M. R. Hirsch, C. Goridis, M. S. Ghandour, O. K. Langley, and G. Gombos (1982) A new brain cell surface glycoprotein identified by a monoclonal antibody. Neuroscience 7: 239-250.

Hockfield, S., and R. D. G. McKay (1983) A surface antigen expressed by a subset of neurons in the vertebrate central nervous system. Proc. Natl. Acad. Sci. USA 80: 5758-5761.

Jorgenson, O. S. (1981) Neuronal membrane D2-protein during rat brain ontogeny. J. Neurochem. 37: 939-946.

Kennet, R. H., T. J. McKearn, and K. B. Bechtol (1980) Methods for the production and characterization of monoclonal antibodies. In Monoclonal Antibodies (Appendix), R. H. Kennet, T. J. McKearn, and K. B. Bechtol, eds., Plenum, New York.

Kohler, G., and C. Milstein (1975) Continuous cultures of fused cells secreting antibody of predefined specificity. Nature 256: 495-497.

Laskey, R. A., and A. D. Mills (1975) Quantitative film detection of ${ }^{3} \mathrm{H}$ and ${ }^{14} \mathrm{C}$ in polyacrylamide gels by fluorography. Eur. J. Biochem. 56: 335-341

Lee, V. M., L. A. Greene, and M. L. Shelanski (1980a) Differential cytotoxic activities of antisera against nerve growth factor-treated and -untreated clonal pheochromocytoma cells. Neuroscience 5: 19791987.

Lee, V. M., M. L. Shelanski, and L. A. Greene (1980b) Characterization of antisera raised against cultured rat sympathetic neurons. Neuroscience 5: 2239-2245.

Lee, V. M., L. A. Grecnc, and M. L. Shelanski (1981) Identification of neural and adrenal medullary surface membrane glycoproteins recognized by antisera to cultured rat sympathetic neurons and $\mathrm{PC} 12$ pheochromocytoma cells. Neuroscience 6: 2773-2786.

Levitt, P. (1984) A monoclonal antibody to limbic system neurons. Science 223: 299-301.

Lohmann, S. M., U. Walter, P. E. Miller, P. Greengard, and P. de Camilli (1981) Immunohistochemical localization of cyclic GMP-dependent protein kinase in mammalian brain. Proc. Natl. Acad. Sci. USA 78: 653-657.

Margolis, R. K., S. R. J. Slaton, and R. U. Margolis (1983) Complex carbohydrates of cultured PC12 pheochromocytoma cells. Effects of nerve growth factor and comparison with neonatal and mature rat brain. J. Biol. Chem. 258: 4110-4117.

McGuirc, J. C., L. A. Grcenc, and A. V. Furano (1978) Nerve growth factor stimulates incorporation of fucose of glucosamine into an external glycoprotein in cultured rat PC12 pheochromocytoma cells. Cell 15: 357-365.

McKay, R. D. G., and S. J. Hockfield (1982) Monoclonal antibodies distinguish antigenically discrete neuronal types in the vertebrate central nervous system. Proc. Natl. Acad. Sci. USA 79: 6747-6751.
Michl, J., M. M. Picczouka, J. C. Unkeless, and S. C. Silverstein (1979) Effects of immobilized immune complexes on Fc- and complementreceptor function in resident and thioglycollate-elicited mouse peritoneal macrophages. J. Exp. Med. 150:607.

Ouchterlony, O. (1968) Handbook of Immunodiffusion and Immunoelectrophoretic Techniques, Ann Arbor Science, Ann Arbor, MI.

Peters, A., and E. G. Jones (eds.) (1984) Cerebral Cortex. Volume I: Cellular Elements of the Cerebral Cortex, Plenum, New York.

Reeber, A., G. Vincendon, and J. P. Zanetta (1981) Isolation and immunohistochemical localization of a "Purkinje cell specific glycoprotein subunit" from rat cerebellum. Brain Res. 229: 53-65.

Richter-Landsberg, C., V. M. Lee, S. R. J. Salton, M. L. Shelanski, and L. A. Greene (1984) Release of the NILE and other glycoproteins from cultured $\mathrm{PC} 12$ rat pheochromocytoma cells and sympathetic neurons. J. Neurochem. 43: 841-848.

Rougon, G., H. Deagostini-Bazi, M. Hirn, and C. Goridis (1982) Tissue- and developmental stage-specific forms of a neural cell surface antigen linked to differences in glycosylation of a common polypeptide. EMBO J. 1: 1239-1244.

Salton, S. R. J., C. Richter-Landsberg, L. A. Greene, and M. L. Shelanski (1983a) Nerve growth factor-inducible large external (NILE) glycoprotein: Studies of a central and peripheral neuronal marker. J. Neurosci. 3: 441-454.

Salton, S. R. J., M. L. Shelanski, and L. A. Greene (1983b) Biochemical properties of the nerve growth factor-inducible large external (NILE) glycoprotein. J. Neurosci. 3: 2420-2430.

Schnitzler, S., S. U. Kim, and M. Schachner (1984a) Specificity of monoclonal antibody $\mathrm{N} 1$ for cell surfaces of mouse central nervous system neurones. Dev. Brain Res. 15: 21-32.

Schnitzler, J., S. U. Kim, and M. Schachner (1984b) Some immature tetanus-toxin-positive cells share antigenic properties with subclasses of glial cells. An immunofluorescence study in the developing nervous system of the mouse using a new monoclonal antibody S1. Dev. Brain Res. 16: 203-217.

Stallcup, W. B., and L. L. Beasley (1985) Involvement of the nerve growth factor-inducible large external glycoprotein (NILE) in neurite fasciculation in primary cultures of rat brain. Proc. Natl. Acad. Sci. USA 82: 1276-1280.

Stallcup, W. B., L. L. Beasley, and J. M. Levine (1985) Antibody against nerve growth factor-inducible large external (NILE) glycoprotein labels nerve fiber tracts in the developing nervous system. $J$. Neurosci. 5: 1090-1101.

Sweadner, K. J. (1983a) Post-translational modification and evoked release of two large surface proteins of sympathetic neurons. J. Neurosci. 3: 2504-2517

Sweadner, K. J. (1983b) Size, shape, and solubility of a class of releasable cell surface proteins of sympathetic neurons. J. Neurosci. 3: 2518-2524.

Vulliamy, T., S. Rattray, and R. Mirsky (1981) Cell-surface antigen distinguishes sensory and autonomic peripheral neurones from central neurones. Nature 291: 418-420.

Webb, M., and A. N. Barclay (1984) Localization of the MRC OX-2 glycoprotein on the surfaces of neurones. J. Neurochem. 43: 10611067.

Weber, A., and M. Schachner (1982) Development and expression of cytoplasmic antigens in Purkinje cells recognized by monoclonal antibodies. Studies in neurologically mutant mice. Cell Tissue Res. 227: 659-676.

Wood, J. N., L. Hudson, T. M. Jessel, and M. Yamamoto (1982) A monoclonal antibody defining antigenic determinants on subpopulations of mammalian neurones and Trypanosoma cruzi parasites. Nature 296: 34-38.

Woodhams, P., J. Mallet, R. Balazs, and J.-P. Changeux (1979) Immunological studies on the Purkinje cells from rat and mouse cerebella. II. Immunohistochemical specificity of the antiscra to Purkinje cells. Dev. Biol. 72: 320-326.

Zomzely-Neurath, C. E., and W. A. Walker (1980) Nervous systemspecific proteins: 14-3-2 protein, neuron-specific enolase, and S-100 protein. In Proteins of the Nervous System, R. A. Bradshaw and D. M. Schneider, eds., Raven, NY. 